\title{
PENGEMBANGAN ALAT UKUR KESANTUNAN BERBAHASA JAWA DALAM KOMUNIKASI BERSEMUKA FORMAL
}

\author{
Siti Mulyani, Endang Nurhayati, Avi Meilawati \\ Universitas Negeri Yogyakarta \\ siti_mulyani@uny.ac.id, endang_nurhayati@uny.ac.id, avimeilawati@uny.ac.id
}

\begin{abstract}
Abstrak
Penelitian ini bertujuan untuk mengembangkan draf alat ukur kesantunan berbahasa Jawa dalam situasi bersemuka formal. Penelitian ini mempergunakan pendekatan research and development $(R \& D)$ berupa alat ukur kesantunan berbahasa Jawa sesuai dengan jenis tindak tuturnya. Subjek penelitian di tahun pertama ini meliputi para pendidik bahasa Jawa baik di tataran SLTP maupun tataran SLTA, maupun di perguruan tinggi yang diprediksi telah mempergunakan bahasa Jawa sebagai alat komunikasi secara santun. Lokasi penelitian adalah Yogyakarta.Pengumpulan data dilakukan dilakukan dengan survey-angket, observasi, dan dokumentasi. Analisis data dilakukan dengan teknik deskriptif kualitatif dan kuantitatif. Analisis kualitatif diperguakan untuk mendeskripsikan jenis tindak tutur berbahasa Jawa dan aspek dalam alat ukur kesantunan tindak tuturnya, kuantitatif untuk mengetahuai skala kesantunannya. Berdasarkan jenisnya tindak tuturnya yang terdapat dalam proses komunikasi bersemuka berbahasa Jawa pada proses pembelajaran dapat dibedakan menjadi lima jenis tidak tutur, yaitu: tindak tutur asertif, ekspresif, direktif, deklaratif dan komisif. Tindak tutur komisif merupakan tindak tutur yang tidak produktif. Suatu tuturan dapat dikategorikan menjadi suatu tuturan yang sangat santun, tuturan yang santun, agak santun, kurang santun , atau tuturan yang sangat tidak santun. Tingkat kesopanan suatu tuturan ditentukan oleh berbagai faktor yaitu mengandung maksim kesantunan atau tidak, sesuai tidak dengan tingkat tutur, ada tidaknya kinesik yang sesuai, nada suara yang sesuai, siap diri, tujuan dari pembicaraan, kesesuaian denga konteks, ada tidaknya sapaan, serta ada tidaknya penanda kesantunan.
\end{abstract}

Kata Kunci: kesantunan, komunikasi formal

\begin{abstract}
This study aims to develop a draft of Javanese politeness tools in a formal situation. This research uses research and development approach $(R \& D)$ in the form of measuring tools politeness of Javanese in accordance with the type of speech acts. Research subjects in this first year include the Javanese language educators both in junior high and high school level, as well as in universities that are predicted to have used the Java language as a means of polite communication. The research location is Yogyakarta. Data collection is done by survey-questionnaire, observation, and documentation. Data analysis was done by qualitative and quantitative descriptive technique. Qualitative analysis is used to describe the type of speech acts in Javanese language and aspects in the measuring tool of politeness of speech acts, quantitative to know the scale of politeness. Based on the type of speech acts contained in the process of communication in the language of Javanese learning process can be divided into five types of speechless, namely: assertive speech acts, expressive, directive, declarative and commissive. Commissive speech acts are unproductive speech acts. A speech can be categorized into a very polite speech, polite, somewhat polite, or polite speech. The level of decency of a speech is determined by various factors that contain the maxim of politeness or not, in accordance with not the level of speech, the presence or absence of the appropriate
\end{abstract}


kinesik, the tone of the appropriate voice, ready yourself, the purpose of the conversation, conformity with the context, whether there is a greeting, markers of politeness.

Keywords: politeness, formal communication

\section{PENDAHULUAN}

Kesantunan berbahasa merupakan salah satu butir penentu keberhasilan seseorang dalam berkomunikasi. Banyak aspek yang dibutuhkan seseorang untuk santun berbahasa dan lancar tanpa kendala komunikasinya,aspek-aspek yang dimaksud antara lain pilihan kata, modus kalimat yang digunakan, cara penyampaian pesan/isi tuturan, dan konteks tuturan saat terjadinya peristiwa tutur. Dalam bidang pragmatik kajian yang menyangkut aspekaspek tersebut disebut kajian tindak tutur. Indikator kesantunan berbahasa suatu bahasa atau budaya suatu bahasa berbeda dengan indikator kesantunan bahasa yang lain, hal tersebut tertantung pada latar belakang budaya pemakai bahasa itu. Indikator kesantunan bahasa Indonesia berbeda dengan indikator kesantunan bahasa Jawa karena masing-masing bahasa tersebut memiliki kaidah pemakaian bahasa yang berbeda.

Kajian ini merupakan kajian yang mengungkapkan pola kesantunan berbahasa, agar tercipta kenyamanan antarpelibat tutur, atau njaga rasa menurut tradisi bertutur Jawa. Unsur yang terkandung di dalam njaga rasa adalah penghargaan atau penghormatan terhadap mitra tutur, penyampaian pesan sesuai maksud, pilihan bahasa yang santun dan jelas, serta dibarengi situasi tutur yang tepat. Peristiwa semacam ini oleh orang Jawa dikatakan sebagai peristiwa tutur yang sesuai dengan unggah-ungguh basa.

Di jaman serba instan seperti saat ini pembelajaran unggah-ungguh basa menjadi hal yang agak sulit dilakukan. Hal ini dikarenakan ukuran atau parameter berkomunikasi mulai melentur karena terjadi percampuran budaya akibat sistem komunikasi dan informasi yang cukup mudah diakses. Untuk mengurai permasalahan tersebut diperlukan parameter yang dapat membawa para pelibat tutur merasa nyaman dalam berkomunikasi dan tidak melanggar kesantunan. Dalam tradisi Jawa ada seperangkat aturan yang dijadikan parameter yaitu ketepatan pemilihan tuturan yang diatur oleh undha-usuking basa, suasana berujar atau empan papan dan mulat sarira atau mampu memposisikan diri sesuai strata sosialnya, dalam rangka njaga rasa.

Untuk itu pada kesempatan ini akan dikaji tentang tindak tutur dalam bahasa Jawa dalam rangka menyusun parameter kesantunan dan tata krama berkomunikasi dalam bahasa Jawa di masyarakat Jawa. Adapun permasalahan-permasalahan yang dapat diidentifikasi dari latar belakang tersebut antara lain: jenis tindak tutur berbahasa Jawa, wujud tuturan berbahasa Jawa yang santun, penanda-penanda kesantunan berbahasa Jawa, ciri-ciri bertutur santun dalam budaya Jawa, dan unsur ekstralingual yang menjadi dasar penentu kesantunan berbahasa Jawa dalam masyarakat tutur Jawa.

Kesantunan berbahasa secara umum merujuk kepada penggunaan bahasa yang baik, sopan, beradab, memancarkan pribadi mulia dan menujukkanpenghormatan kepada pihak yang menjadi mitra bicaranya. Kesantunan berbahasa tercermin dalam tatacara berkomunikasi melalui tanda verbal atau tatacara berbahasa. Ketika berkomunikasi, komunikan-komunikator tunduk pada norma-norma budaya, tidak hanya sekedar menyampaikan ide yang dipikirkan, dirasakan. Tatacara berbahasa harus sesuai 
dengan kovensi-kovensi budaya yang ada dalam masyarakat tempat dipergunakannya bahasa tersebut sebagai alat berkomunikasi. Apabila tatacara berbahasa seseorang tidak sesuai dengan normanorma budaya yang berlaku, maka ia akan mendapatkan nilai negatif, misalnya dituduh sebagai orang yang sombong, angkuh, tak acuh, egois, tidak beradat, bahkan tidak berbudaya.

Pemakaian bahasa untuk berkomunikasi oleh masyarakat penuturnya terikat oleh normanorma, yaitu norma kebahasaan maupun norma budaya. Pemakai bahasa menyampaikan pendapat, gagasan atau perasaan dengan memperhatikan kaidah kebahasaan maupun kaidah budaya masyarakat penuturnya dapat dikatakan bahwa yang bersangkutan mempergunakan bahasa dengan santun.Kesantunan berbahasa adalah kesopanan dan kehalusan pemakaian bahasa dalam berinteraksi dengan orang lain baik secara lisan maupun secara tertulis.

Tatacara berbahasa yang meliputi norma bahasa dan norma budaya sangat penting diperhatikan oleh para peserta komunikasi (komunikator dan komunikan) demi kelancaran proses komunikasi. Terlebih jika proses komunikasi tersebut dijalin dengan saran bahasa Jawa. Pemakaian bahasa Jawa sebagai sarana komunikasi terikat oleh norma yang sangat rinci dengan adanya tingkat tutur jika dibandingkan dengan bahasa Indonesia. Dengan mengetahui tatacara berbahasa diharapkan orang lebih bisa menjalin proses komunikkasi dengan baik masingmasing dapat memahami pesan yang disampaikan dalam komunikasi karena tatacara berbahasa bertujuan mengatur serangkaian hal berikut.

1. Apa yang sebaiknya dikatakan pada waktu dan keadaan tertentu.

2. Ragam bahasa apa yang sewajarnya dipakai dalam situasi tertentu.
3. Kapan dan bagaimana giliran berbicara dan pembicaraan dilaksanakan.

4. Bagaimana mengatur kenyaringan penjedaan suara ketika berbicara.

5. Bagaimana sikap dan gerakan anggota tubuh ketika berbicara.

6. Kapan harus diam dan mengakhiri pembicaraan.

Seperti yang telah disampikan di depan bahwa tatacara berbahasa seseorang dipengaruhi norma-norma budaya masyarakat pemilik bahasa tersebut. Tatacara berbahasa orang Jawa Timur berbeda dengan tatacara berbahasa orang Cilacap meskipun mereka sama-sama mempergunakan bahasa Jawa sebagai lat komunikasi. Begitu juga, tatacara berbahasa orang Jawa berbeda dengan tatacara berbahasa orang Batak meskipun mereka sama-sama mempergunakan Bahasa Indonesia sebagai alat komunikasinya. Hal ini menunjukkan bahwa kebudayaan yang sudah mendarah daging pada diri seseorang berpengaruh pada pola berbahasanya. Itulah sebabnya kita perlu mempelajari atau memahami norma-norma budaya di samping mempelajari bahasa. Sebab, tatacara berbahasa yang mengikuti norma-norma budaya akan menghasilkan kesantunan berbahasa (Ramlanari, 2010)

Wijana (1996: 55) mengungkapkan bahwa sebagai retorika interpersonal, pragmatik membutuhkan prinsip kesopanan (politeness principle). Prinsip kesopanan ini berhubungan dengan peserta percakapan, yakni diri sendiri si penutur (self) dan orang lain (other) terdiri atas mitra tutur atau orang kedua dan orang ketiga yang dibicarakan penutur dan lawan tutur. Senada denganhal itu, Rahardi (2005: 60-66) menjelaskan bahwa dalam bertindak tutur yang santun, agar pesan dapat disampaikan dengan baik pada peserta tutur, dalam menjalin proses komunikasi perlu mempertimbangkan prinsip-prinsip kesantunan berbahasa. 
Leech (1983: 206-207)menyebutkan bahwa prinsip kesantunan berbahasa meliputi beberapa hal berikut : Maksim Kearifan (Tact Maxim); Maksim Kedermawanan (Generosity Maxim); Maksim Pujian (Approbation Maxim); Maksim Kerendahan hati (Modesty Maxim); Maksim Kesepakatan (Agreement Maxim); Maksim Simpati (Sympathy Maxi). Rahardi (2005) menyatakan bahwa skala kesantunan Leech diklasifikasikan menjadi lima hal berikut.

1. Cost benefit scale atau skala kerugian dan keuntungan, skala ini merujuk kepada besarkecilnya kerugian dan keuntungan sebagai akibat adanya sebuah tindak tutur.

2. Optionality scale atau skala pilihan, menunjuk kepada banyak sedikitnya pilihan (options) yang disampaikan penutur kepada si mitra tutur melalui tuturannya.

3. Indirectness scale atau skala ketidaklangsungan menunjuk kepada peringkat langsung atau tidak langsungnya maksud sebuah tuturan.

4. Authority scale atau skala keotoritasan menunjuk kepada hubungan status sosial antara penutur dan mitra tutur yang terlibat dalam pertuturan.

5. Social distance scale atau skala jarak sosial menunjuk kepada peringkat hubungan sosial antara penutur dan mitra tutur yang terlibat dalam pertuturan. Ada kecenderungan bahwa semakin dekat jarak peringkat sosial di antara keduanya, akan menjadi semakin kurang santunlah tuturan itu. Demikian sebaliknya, semakin jauh jarak peringkat sosial antara penutur dengan mitra tutur, akan semakin santunlah tuturan yang digunakan itu.

\section{METODE}

Penelitian ini mempergunakan pendekatan research and development $(R$ $\& D)$. Produk dari penelitian ini berupa alat ukur kesantunan berbahasa Jawa sesuai dengan jenis tindak tuturnya.

\section{Subjek dan Lokasi Penelitian}

Subjek penelitian ini adalah penutur bahasa Jawa yang diprediksi telah mempergunakan bahasa Jawa sebagai alat komunikasi secara santun. Subjek penelitian di tahun pertama ini meliputi para pendidik bahasa Jawa baik di tataran SLTP maupun tataran SLTA, maupun di perguruan tinggi yang diprediksi telah mempergunakan bahasa Jawa sebagai alat komunikasi secara santun.Lokasi penelitian adalah Yogyakarta khususnya di wilayah Kabupaten Sleman.

\section{Teknik Pengumpulan Data}

Pengumpulan data untuk penelitian mengembangkan alat ukur kesantunan berbahasa Jawa dalam situasi bersemuka formal yang dilakukan pada tahun pertama dilakukan dengan survey-angket, observasi, wawancara, dan dokumentasi.

\section{Instrumen Penelitian}

Sesuai dengan langkah-langkah yang dilakukan dalam pengumpulan data pada penelitian ini, maka instrumen penelitian yang dipergunakan untuk mengumpulkan data pada tahun pertama adalah lembar observasi dan pedoman wawancara.

\section{Teknik Analisis Data}

Analisis data tahun pertama dilakukan dengan teknik deskriptif kualitatif dan kuantitatif. Analisis kualitatif diperguakan untuk mendeskripsikan jenis tindak tutur berbahasa Jawa dan aspek dalam alat ukur kesantunan tindak tuturnya, kuantitatif untuk mengetahuai skala kesantunannya.

\section{HASIL DAN PEMBAHASAN}

Berikut dipaparkan tabel yang menunjukkan jenis-jenis tindak tutur berbahasa Jawa dalam komunikasi 
bersemuka formal pada proses pembelajaran bahasa Jawa, dan tingkat

kesantunannya yang ditemukan pada penelitian ini.

Tabel 1: Jenis Tindak Tutur Berbahasa Jawa pada Komunikasi Pembelajaran Formal Bersemuka dan Tingkat Kesopanannya

\begin{tabular}{|c|c|c|c|}
\hline $\begin{array}{c}\text { Jenis Tindak } \\
\text { Tutur }\end{array}$ & $\begin{array}{c}\text { Tingkat } \\
\text { Kesopanan }\end{array}$ & Ragam Bahasa & Penutur \\
\hline \multirow[t]{10}{*}{ 1. Asertif } & a. sangat santun & krama alus & guru - kepala sekolah \\
\hline & b. santun & 1) krama alus & mahasiswa - dosen \\
\hline & & 2) krama & mahasiswa - dosen \\
\hline & c. agak santun & 1) krama - ngoko & dosen - mahasiswa \\
\hline & & 2) madya & dosen - mahasiswa \\
\hline & & 3) ngoko alus & guru -siswa \\
\hline & & 4) ngoko lugu & guru - siswa \\
\hline & d. kurang santun & 1) madya & dosen - mahasiswa \\
\hline & & & murid - guru \\
\hline & & 2) ngoko lugu & murid - guru \\
\hline \multirow[t]{5}{*}{ 2. Ekspresif } & a. santun & 1) krama alus & kepala sekolah guru \\
\hline & & & kepala sekolah - siswa \\
\hline & & 2) krama & mahasiswa dosen \\
\hline & & 3) ngoko alus & guru -siswa \\
\hline & b. kurang santun & ngoko lugu & teman sebaya \\
\hline \multirow[t]{2}{*}{ 3. Direktif } & a. kurang santun & ngoko lugu & teman sebaya \\
\hline & $\begin{array}{l}\text { b. sangat tidak } \\
\text { santun }\end{array}$ & ngoko lugu & teman sebaya \\
\hline 4. Deklaratif & $\begin{array}{l}\text { sangat tidak } \\
\text { santun }\end{array}$ & ngoko lugu & teman sebaya \\
\hline 5. Komisif & kurang santun & krama alus & mahasiswa - dosen \\
\hline
\end{tabular}

Dari tabel di atas dapat diketahui bahwajenis-jenis tindak tutur berbahasa Jawa dalam komunikasi bersemuka formal padaproses pembelajaran bahasa Jawa ada 5 (lima) jenis, yaitu tindak tutur asertif, ekspresif, direktif, deklaratif, dan komisif. Tindak tutur asertif dapat dikelompokkan dalam empat tingkat kesopanan, yaitu: sangat santun, santun, agak santun, dan kurang santun. Tindak tutur ekspresif dapat dikelompokkan menjadi dua yaitu tindak tutur yang santun dan kurang santun. Tindak tutur ekspresif juuga dapat diigolongkan menjadi dua golongan tindak tutur yang santun dan kurang santun. Tidak tutur direktif terdiri atas tindak tutur dengan tingkat tutur yang kurang santun dan tindak tutur yang sangat tidak santun. Tindak tutur deklaratif hanya ditemukan tindak tutur dengan tingkat kesantunan sangat tidak santun dan tindak tutur komisif hanya ditemukan tidak tutur dengan tingkat kesopanan kurang sopan.

Tindak tutur asertif sangat santun diekspresikan degan mempergunakan ragam bahasa Jawa krama alus oleh seorang guru kepada kepala sekolah. Tindak tutur asertif santun dipergunakan oleh mahasiswa kepada dosennya dengan mempergunakan ragam bahasa krama halus dan krama. Tindak tutur asertif agak santun diergunakan oleh dosen kepada mahasiswa dengan ragam bahasa 
krama - ngoko dan madya, selin itu dipergunakan pula oleh guru kepada siswa dengan memeprgunakan ragam bahasa ngoko alus dan ngoko lugu. Tindak tutur asertif kurang santun dipergunakan oleh dosen kepada mahasiswa dan dipergunakan siswa kepada guru dengan mempergunakan bahasa Jawa ragam madya, selain itu dilisankan siswa kepada gurunya dengan ragam bahasa Jawa ngoko lugu.

Tindak tutur ekspresif dengan tingkat kesantunan santun diekspresikan dengan mempergunakan ragam krama alus oleh kepala sekolah kepada guru dan kepada siswa. Tindak tutur ekspresif santun selain diekspresikan dengan mempergunakan ragam krama alus juga dipergunakan ragam krama oleh mahasiswa kepada dosen dan ngoko alus dipergunakan oleh guru kepada siswa. Tindak tutur ekspresif kurang santun diperguanakan seseorang siswa kepada teman sebayanya dengan mempergunakan ragam ngoko lugu.

Tindak tutur direktif yang ditemukan memiliki tingkat kesantunan kurang santun dan sangat tidak santun yang dipergunakan oleh seorang siswa kepada teman sebaya dengan menggunakan ragam ngoko lugu, demikian pula yang tingkat kesantunan sangat tidak santun. Tindak tutur deklaratif yang ditemukan memiliki tingkat kesantunan sangat tidak santun yang dipegunakan oleh seorang siswa pada teman sebayanya dengan ragam ngoko lugu. Tindak tutur komisif memiliki tingkat kesantunankurang santun yang dipergunakan oleh seorang siswa pada teman sebayanya dengan ragam krama halus.

Berdasarakan paparan pada hasil penelitian dapat diketahui bahwa tingkat kesopanan sebuah tindak tutur ditentukan oleh berbagai faktor. Faktor-faktor tersebut di antaranya pemilihan unggah-ungguh yak terkait dengan pemilihan kosa kata yang dipergunakan untuk mengekspresikan tindak tuturnya, ada tidaknya sapaan, tujuan berbicara, tepat tidaknya pilihan kosa kata dengan situasi pertuturan atau konteks, sikap diri penutur dalam hal ini ada tidak rasa angkuh atau sombong, nada suara, dan juga kinesik gerak anggota tubuh sewaktu berbicara juga merupakan penentu tindak tutur yang dilakukan tersebut termasuk tindak tutur yang memiliki tingkat kesantunan tertentu. Faktor-faktor tersebut memiliki bobot yang hampir imbang dalam menentukan tingkat kesantunan sebuah tuturan. Sebagai contoh tuturan seorang mahasiswa kepada dosennya. Berdasarkan status sosial mahasiswa dalam berkomunikasi dengan dosennya menggunakan ragam krama halus sewaktu meminta ijin untuk tidak mengikuti kuliah karena harus mengikuti upacara bendera tuturannya tersebut disertai dengan nada suara yang rendah dan sikap yang halus dengan ngapurancang wajah agak menunduk, maka tindak tutur mahasiswa tersebut dipersepsi sebagai tuturan yang memiliki tingkat kesopanan yang sopan.

Hal tersebut berbeda dengan mahasiswa yang sama-sama mempergunakan ragam bahasa krama halus dengan sikap yang masuk dalam kategori halus oleh responden tidak dipersepsi sebagai sebuah tuturan yang memiliki tingkat kesopan tinggi. Tuturan tersebut dipersepsi sebagai tuturan yang kurang sopan karena tuturan tersebut berisi permohonan mahasiswa kepada dosennya agar perkuliahan yang kosong tidak usah diganti dengan pertemuan namun cukup diganti dengan tugas. Hal tersebutlah yang dianggap oleh respoden sebagai sesuatu yang tidak etis karena mendahului kehendak dosen yang menurutnya, dosen memiliki otoritas dalam perkuliahan.

Apabila dikaitkan dengan prinsip kesantuan Leech (1983: 206-207)persepsi para responden tersebut sesuai. Dalam pendapatnya tersebut disebutkan bahwa suatu tuturan dikatan sebagai tuturan yang santun apabila memenuhi persyaratan-persyaratan tertentu atau memenuhi kaidah atau maksim tertentu. Kaidah tersebut terkait dengan aspek kearifan, kedermawanan, pujian, rendah hati, kesepakatan, dan kesimpatian. Suatu tuturan dikatakan sebagai tuturan yang 
santun apabila tuturan tersebut merupakan tuturan yang isinya memaksimalkan keuntungan bagi mitra tutur, meminimalkan keuntungan bagi dirinya, yang lebih menghormati mitra tutur, yang merendahan dirinya, yang mengandung kecocokan pendapat dengan mitra tutur, dan memaksimalkan rasa simpati pada mitra tutur.Sebagai contoh yang lain tuturan kepala sekolah kepada seorang guru dipersepsi oleh responden merupakan tuturan yang santun. Hal itu dikarenakan tuturan tersebut isinya yang isinya memaksimalkan keuntungan bagi mitra tutur, meminimalkan keuntungan bagi dirinya, yang lebih menghormati mitra tutur, yang merendahan dirinya, yang mengandung kecocokan pendapat dengan mitra tutur, dan memaksimalkan rasa simpati pada mitra tutur. Dengan demikian persepsi informan sesuai dengan prinsip kesopanan yang disampaikan oleh Leech.

Suatu tuturan memiliki tingkat kesantunan yang tinggi apabila tuturan tersebut banyak mengandung unsur-unsur yang telah disebutkan tadi, semakin sedikit semakin berkuranglah tingkat kesantunan tuturan tersebut. Dengan demikian tingkat kesantunan suatu tuturan dapat dihadapkan secara bergradasi berikut ini.

Tabel 2: Gradasi Tingkat Kesantunan Suatu Tuturan

\begin{tabular}{lr}
\hline Tuturan yang santun & $\begin{array}{r}\text { Tuturan tidak santun } \\
\hline \text { Tingkat tutur sesuai }\end{array}$ \\
\hline Tujuan sesuai konteks & Tingkat tutur tidak sesuai \\
\hline Rendah hati & Tujuan tidak sesuai konteks \\
\hline Ucapan terima kasih yang tulus & Sombong \\
\hline Ucapan lemah lembut & Nada tinggi \\
\hline Memperlakukan orang lain baik & Merima kasih basa-basi \\
\hline Menggunakan penanda hormat & Tanpa penanda hormat \\
\hline Memperbanyak kecocokan & Minim rasa kecocokan \\
\hline Menghargai orang lain & Meremehkan orang lain \\
\hline
\end{tabular}

Lebih lanjut jika dilihat dari pemakai tingkat tutur bahasa Jawa dalam proses bersemuka berbahasa Jawa dalam pembelajaran bahasa Jawa agak menyimpang dari kaidah umum. Persisnya seorang guru yang memilki status sosial tinggi mestinya bila tuturannya mempergunakan tingkat tutur ngoko pada siswanya sudah masuk dalam kategori tuturan yang sopan. Namun menurut respoden tidak demikian. Meskipun memiliki status yang tinggi dalam proses pembelajaran bahasa Jawa menurut responden hendaknya guru mempergunakan tingkat tutur krama sebagai wahana untuk memberikan suri tauladan bagi siswa mengenai cara pengguaan tingkat tutur krama.

\section{SIMPULAN}

Dari hasil penelitian dan pembahasa dapat disimpulkan beberapa hal berikut.

1. Berdasarkan jenisnya tindak tuturnya yang terdapat dalam proses komunikasi bersemuka berbahasa Jawa pada proses pembelajaran dapat dibedakan menjadi lima jenis tidak tutur, yaitu: tindak tutur asertif, ekspresif, direktif, deklaratif dan komisif. Tindak tutur komisif merupakan tindak tutur yang tidak produktif.

2. Suatu tuturan dapat dikategorikan menjadi suatu tuturan yang sangat santun, tuturan yang santun, agak santun, kurang santun, atau tuturan yang sangat tidak santun.

3. Tingkat kesopanan suatu tuturan ditentukan oleh berbagai faktor yaitu mengandung maksim kesantunan atau 
tidak, sesuai tidak dengan tingkat tutur, ada tidaknya kinesik yang sesuai, nada suara yang sesuai, siap diri, tujuan dari pembicaraan, kesesuaian denga konteks, ada tidaknya sapaan, serta ada tidaknya penanda kesantunan.

Penelitian ini merupakan penelitian pengembangan alat ukur kesantunan berbahasa Jawa dalam komunikasi bersemuka yang harapannya menghasilkan menyusun parameter kesantunan dan tata krama berkomunikasi dalam bahasa Jawa di masyarakat Jawa. Untuk mencapai hasil itu memelukan penelitian yang panjang. Namun demikian penelitian ini telah berhasil mewujudkan draf alat ukur kesantunan berbahasa Jawa bersemuka formal dalam prose pembelajaran bahasa Jawa. Karena masih berujud drafmaka alat ukur ini belum dapat dipergunakan sebagai instrumen untuk mengukur kesantunan suatu tindak tutur. Instrumen ini dapat dipergunakan setelah melalui tataran uji coba terlebih dahulu.

\section{PUSTAKA RUJUKAN}

Djajasudarma.1993. Bab III Metode Penelitian.

http://digilib.unila.ac.id/3193/17/BAB\% 20111.pdfDunduh: Senin, 18 April 2016, 13.03.

Kaelan. 2005. MetodePenelitianKualitatifBidangFilsaf at. Yogyakarta: Paradigma.

Kunjana Rahardi.2005. Pragmatik: Kesantunan Imperatif Bahasa Indonesia. Jakarta: Erlangga

Leech Geoffrey.1990. Principles of Pragmatics. London.New York: Longman. Linguistics. Library

Nurhayati, Endang. 2006. Ajaran Hidup Dan Fasafah Dalam Naskah Jatipusaka Makutharaja Relevansinya Dengan Kehidupan Dewasa ini. Dalam Filsafat Dan Ajaran Hidup Dalam Khasanah Budaya Jawa Keraton Yogyakarta.
Yogyakarta: YKII bekerja sana dengan UIN Sunan Kalijaga Yogyakarta.

2015. Pembelajaran Unggahungguh Basa Pada Guru-guru SD seKabupaten Sleman. (artikel PPM)

Pranowo.2009. Berbahasa Secara Santun .Yogyakarta: Pustaka Pelajar

Rustono. 1999. Pokok-Pokok Pragmatik. Semarang: CV. IKIP Semarang Press.

Searle, J.R. 1969. Speech Act. Cambridge: CambridgeUniversity Press.

Widodo, Erna dan Mukhtar. 2000. Konstruksi ke Arah Penelitian Deskriptif. Yogyakarta: Avyrouz.

Wijana, I Dewa Putu. 1996. DasarDasar Pragmatik. Dasar-Dasar Pragmatik. Yogyakarta: Penerbit Andi.

Zamzani. 2010. Pengembangan Alat Ukur Kesantuanan Bahasa Indonesia dalam Interaksi Sosial Formal Bersemuka. Laporan Penelitian

https://www.scribd.com/doc/17067590/Peng ertian-Kesantunan

https://www.scribd.com/doc/51894144/KO NSEP-KESANTUNAN-BAHASA

http://wartawarga.gunadarma.ac.id/2009/10/ programatik/diakses pada tanggal30 Oktober 2009.

\section{UCAPAN TERIMA KASIH}

Terima kasih penulis ucapkan kepada pihakpihak yang ikut membantu dalam penelitian ini, tidak lupa penulis menyampaikan terimakasih kepada tim penyunting jurnal Lokabasa atas dimuatnya penelitian ini. 